\title{
OBITUARY NOTICE
}

\section{Henri Cordier}

[The following obituary notice, which appeared in The Times of 12 th May, 1925, is reprinted here with the writer's permission.]

Although the name of Henri Cordier was almost as well known among scholars in England as in France, his death on 16th March of this year fassed unnoticed here. In this country he is best known as the man who was entrusted with the important task of preparing new editions of Sir Henry Yule's two great masterpieces, "Marco Polo" and "Cathay and the Way Thither". In view of the astonishing progress made in the field of Central Asian research since the first appearance of these books-thanks to the discoveries of Stein, von le Coq, Pelliott, and others-it was no easy matter to find a competent editor. But in Henri Cordier exactly the right man was available, and he carried out his task in a manner worthy both of the subject and the memory of Sir Henry Yule.

Though Cordier spent eight years in China, he never claimed to be a Chinese scholar, for his studies all lay in the direction of bringing together and analysing the vast materials for the history, religion, and culture of China and the Far East, contained in the writings of mediaeval and modern European scholars and travellers. There were no limits to his industry, and the long list of his contributions to sinology and other subjects bears witness to an almost incredible literary activity extending over a period of 55 years. A complete list of all his books, articles, and reviews, which was published on the occasion of bis 75th birthday, comprises no less than 1,147 entries.

Of the many works he published the most important was his "Bibliotheca Sinica", a bibliographical dictionary of 
works relating to the Chinese Empire, which began to appear in 1881. The last fasciculus, which was published in 1924, brought the number of entries up to 4,439 . This great work of reference, which is indispensable to all students of the Far East, will always remain the chief monument to Cordier's memory. It is only to be regretted that at the time of his death the all-important index was incomplete.

At gatherings of Orientalists Cordier was always a prominent figure, and when he attended the Centenary of the Royal Asiatic Society in London in 1923, he seemed, in spite of his age, as full as ever of intellectual vigour and enthusiasm. No man during the last half century did more than Cordier to further and encourage Chinese researches; it was he who originally inspired the great French sinologue, Edouard Chavannes, to take up Chinese ; it was he who with Schlegel in 1890 founded the now famous journal T"oung Pao; and there can be few students of things Chinese who are not under some obligation to this great scholar, who was always ready to place the fruits of his vast learning at the disposal of all inquirers.

Henri Cordier was born in New Orleans, U.S.A., on 8th August, 1849. In 1852 he landed at Havre. After studying both in France and in England, he went to China in 1869 , where he remained till 1876. While there he became honorary librarian to the North China Branch of the Royal Asiatic Society in Shanghai. In 1881 he became lecturer on the history, geography, and legislation of the Far East, in the Ecole des Langues Orientales Vivantes, Paris. Apart from the many distinctions he gained in his own country, he was made, in 1893, an honorary member of the Royal Asiatic Society, London, and in 1921 was elected foreign corresponding member of the British Academy.

E. D. R. 